ACTA AGROBOTANICA

Vol. 58 , z. 2 - 2005

s. $179-188$

\title{
Zbiorowiska mikroorganizmów w glebie spod leśnej uprawy żeń-szenia amerykańskiego
}

\section{ALINA PASTUCHA ${ }^{1}$, BARBARA KOLODZIEJ ${ }^{2}$}

\author{
${ }^{1}$ Katedra Fitopatologii, Akademia Rolnicza w Lublinie, \\ ul. Leszczyńskiego 7, 20-069 Lublin, e-mail: alina.pastucha@ar.lublin.pl \\ Department of Phytopathology, University of Agriculture, \\ 7 Leszczyńskiego Str., 20-069 Lublin \\ ${ }^{2}$ Katedra Roślin Przemysłowych i Leczniczych Akademia Rolnicza w Lublinie, \\ ul. Akademicka 15, 20-950 Lublin, e-mail: barbara.kolodziej@ar.lublin.pl \\ Department of Industrial and Medicinal Plants, University of Agriculture, \\ 15 Akademicka Str., 20-950 Lublin \\ Microbial communities in the soil under forest-grown American ginseng
}

(Otrzymano: 01.04.2005)

\section{Summary}

The investigations were carried out in 2003-2004 on American ginseng (Panax quinquefolium L.) plantation localised in the mixed forest in Trzciniec (Lubelski province). The object of the study was the soil from ginseng culture protected by the biological and chemical method. In the experiment there was also control plot - without any protection during plants vegetation. There were also analysed the infected roots of ginseng plants. Microbiological analyses showed that soil from control plots was characterised by the smallest average total number of bacteria. In $1 \mathrm{~g}$ of dry weight of soil after Polyversum application there was stated the highest number of bacterial colonies from Bacillus and Pseudomonas genus. The highest number of fungal colonies was obtained in $1 \mathrm{~g}$ of dry weight of soil on the control plots.

The highest number of saprophytic fungi (including those with antagonistic character) was obtained from the soil where the biological plant protection was applied.

Generally, independently of a plant protection method, American ginseng plants were affected by Alternaria alternata, Cylindrocarpon spp., Fusarium spp., Pythium irregulare and Rhizoctonia solani.

Key words: soil, American ginseng, Panax quinquefolium L., microorganisms of soil 


\section{WSTĘP}

Żeń-szeń amerykański (Panax quinquefolium L.), pokrewny znanemu od ponad 4000 lat azjatyckiemu gatunkowi (Panax ginseng C.A.Meyer), jest byliną o cennych właściwościach leczniczych, pochodzącąz mieszanych lasów wschodniej części kontynentu północnoamerykańskiego. W stanie dzikim występuje na przepuszczalnych, bogatych w próchnicę, kwaśnych glebach piaszczysto-glinistych, przy czym ocenia się, że w stanie naturalnym obecnie przetrwała niewielka liczba roślin (w Kanadzie ok. 196 tys. sztuk $\mathrm{N}$ a u lt i in., 1998). Surowcem zielarskim żeń-szenia są korzenie, zawierające m.in. saponiny triterpenowe zwane ginsenozydami, odpowiadające za działanie lecznicze. Korzenie uważane są za efektywny adaptogen, tonizujący czynności organizmu, przejawiający również działanie antydiabetyczne, antystresowe, afrodyzjalne, antymiażdżycowe i opóźniający starzenie się (L i , 1995; A t t e le i in., 1999).

Radix ginseng na skalę przemysłową pozyskiwany jest z plantacji polowych, jednakże w ostatnim czasie, szczególnie w USA, Kanadzie, Australii i Chinach rośnie zainteresowanie leśną uprawą żeń-szenia (F o lle t, 1997; N a d e a u i in., 1999). Do zbiorów surowca przystępuje się po 6-9 latach, przy czym uzyskiwane plony są niższe w porównaniu z uprawą polową, lecz surowiec jest nieporównywalnie droższy (F o 11 e t, 1997; B e y f u s s , 1999; $\mathrm{N}$ a d e a u i in., 1999). Z prowadzonych wcześniej badań wynika, że jedno- i dwuletnie rośliny żeń-szenia, mimo iż zawierają ginsenozydy, porażane są przez szereg grzybów patogenicznych jak Alternaria spp., Fusarium spp., Phytophthora spp., Rhizoctonia solani oraz grzyby z rodzaju Pythium (P a r k e i Shotwel1, 1989; Pięta i Berbeć, 1995; 1997; Punja, 1997). Korzenie żeń-szenia $\mathrm{w}$ okresie wegetacji podobnie jak i inne rośliny wydzielają różne związki organiczne do gleby (F u n ck-J en se n i H o cke nhull., 1984). Wydzieliny korzeniowe modyfikują skład populacji mikroorganizmów w glebie. W dostępnej literaturze brak jest informacji dotyczących kształtowania się zbiorowisk drobnoustrojów w glebie pod wpływem uprawy omawianej rośliny.

Celem niniejszej pracy było określenie składu ilościowego i jakościowego mikroorganizmów zasiedlających glebę leśną podczas uprawy żeń-szenia oraz ustalenie gatunków chorobotwórczych porażających korzenie tej rośliny.

\section{MATERIAL I METODY}

Badania prowadzono w latach 2003-2004 na plantacji zlokalizowanej w lesie mieszanym (z przewagą akacji, brzozy brodawkowej i klonu) w Trzcińcu (woj. lubelskie) na piaszczystej glebie leśnej. Gleba ta charakteryzowała się wysoką zawartością próchnicy$-4,85 \%$, bardzo kwaśnym odczynem $\left(\mathrm{pH}_{\mathrm{KCL}}-3,5\right)$, bardzo wysoką zasobnością $\mathrm{w}$ fosfor (261,2 $\mathrm{mg} \cdot \mathrm{kg}^{-1}$ gleby), a niską w potas $\left(58,4 \mathrm{mg} \cdot \mathrm{kg}^{-1}\right.$ gleby) i magnez $\left(13 \mathrm{mg} \cdot \mathrm{kg}^{-1} \mathrm{gle}\right.$ by). W doświadczeniu uwzględniono dwie kombinacje ochrony roślin żeń-szenia:

1 - metoda biologiczna w której nasiona żeń-szenia zaprawiano Polyversum $\left(5 \mathrm{~g} \cdot \mathrm{kg}^{-1}\right.$ nasion) i w okresie wegetacji wykonano trzykrotne podlewanie roślin $2 \%$ roztworem tego biopreparatu 
2 - metoda chemiczna w której nasiona zaprawiano Dithane M $45\left(5 \mathrm{~g} \cdot \mathrm{kg}^{-1}\right.$ nasion), przed wschodami roślin glebę podlano 0,1\% roztworem Amistaru $\left(21 \cdot \mathrm{m}^{-2}\right)$, a w okresie wegetacji co 10 dni stosowano opryskiwanie roślin naprzemiennie: Rovralem WP $50(0,1 \%)$, Bravo $500 \mathrm{~S} \mathrm{C}(0,1 \%)$, Ridomilem Plus WP $(0,1 \%)$, Dithane M45 (0,1\%), Aliette 80 WP $(0,1 \%)$. Dla porównania skuteczności tych metod w doświadczeniu uwzględniono także kombinację kontrolną tj. bez stosowania żadnego zabiegu ochroniarskiego.

W trzeciej dekadzie września 2002 roku na każde poletko o powierzchni $2 \mathrm{~m}^{2}$ (w czterech powtórzeniach) wysiewano stratyfikowane nasiona żeń-szenia amerykańskiego w ilości $20 \mathrm{~g} \cdot \mathrm{pol}^{-1}$.

W czasie wegetacji w każdym roku badań z poszczególnych poletek pobierano korzenie porażonych roślin do laboratoryjnej analizy mikologicznej, którą wykonano według metody opisanej przez P i ęt ę i B e r b e c i a (1995). Każdego roku tj. 2003 i 2004 na początku maja z poszczególnych kombinacji doświadczenia pobierano próbki gleby w celu wykonania analizy mikrobiologicznej sposobem opisanym przez M a r ty n i u k a i in., (1991). W laboratorium glebę z tej samej kombinacji doświadczenia dokładnie wymieszano. $Z$ przygotowanych prób odważono po $10 \mathrm{~g}$ gleby i umieszczono w kolbie $(250 \mathrm{ml})$ z $90 \mathrm{ml}$ sterylnej wody destylowanej, a następnie mieszano na wstrząsarce przez 30 minut. $\mathrm{Z}$ przygotowanego roztworu glebowego sporządzono rozcieńczenia od $10^{-2}$ do $10^{-7}$.

Ogólną liczbę bakterii w $1 \mathrm{~g} \mathrm{~s}$. m. gleby określano w roztworach glebowych o rozcieńczeniach $10^{-5}, 10^{-6}, 10^{-7}$ przy zastosowaniu pożywki Nutrient Agar. Dla określenia liczebności bakterii rodzaju Bacillus w $1 \mathrm{~g} \mathrm{s.} \mathrm{m}$. g. zastosowano rozcieńczenia $10^{-4}, 10^{-5}$, $10^{-6}$ oraz pożywkę Tryptic Soy Agar. Natomiast do określenia liczebności kolonii Pseudomonas spp. użyto rozcieńczeń $10^{-2}, 10^{-3}, 10^{-4}$ stosując pożywkę Pseudomonas Agar F. Ogólną liczbę grzybów w każdej próbie gleby określano na pożywce Martina (1950) przy użyciu rozcieńczeń $10^{-2}, 10^{-3}, 10^{-4}$. Uzyskane izolaty bakterii rodzaju Bacillus (200 izolatów) i Pseudomonas (200 izolatów) oraz wszystkie izolaty wyosobnione z gleby Trichoderma spp. użyto do określenia ich antagonistycznego oddziaływania względem Botrytis cinerea, Fusarium culmorum, F. oxysporum, F. solani, Phoma exigua var. exigua, Pythium irregulare, Rhizoctonia solani i Sclerotinia sclerotiorum według metod opisanych przez M án kę (1974), M arty n i u ka i in., (1991), P i ę tę (1999).

\section{WYNIKI}

W wyniku laboratoryjnej analizy mikologicznej korzeni porażonych roślin żeń-szenia wyizolowano 336 kolonii grzybów należących do 15 różnych gatunków. Najwięcej bo 178 izolatów grzybów uzyskano z korzeni pobranych z kontroli. Znacznie mniej kolonii grzybów wyosobnionozkorzeni pobranych zpoletekzarówno chronionych chemiczniejak i biopreparatem Polyversum (tab. 1). Analiza mikologiczna wykazała, że korzenie żeń-szenia bez względu na kombinację doświadczenia porażane były przez grzyby patogeniczne jak Alternaria alternata, Cylindrocarpon spp., Fusarium spp., Pythium irregulare 
oraz Rhizoctonia solani (tab. 1). Najwięcej kolonii tych grzybów uzyskiwano z korzeni roślin wzrastających w kombinacji kontrolnej. Ponadto izolowano Cladosporium cladosporioides, Epicoccum purpurascens, Rhizopus nigricans oraz grzyby rodzaju Penicillium i Trichoderma (tab. 1).

Tabela 1

Grzyby wyizolowane z korzeni porażonych roślin żeń-szenia (2003-2004)

Table 1

Fungi isolated from infected roots of ginseng plants (2003-2004)

\begin{tabular}{|c|c|c|c|c|}
\hline \multirow{2}{*}{$\begin{array}{l}\text { Gatunek grzyba } \\
\text { Fungus species }\end{array}$} & \multicolumn{4}{|c|}{$\begin{array}{l}\text { Liczba izolatów / Kombinacja doświadczenia } \\
\text { Number of isolates / Experimental combination }\end{array}$} \\
\hline & $\begin{array}{c}\text { Ochrona } \\
\text { biologiczna } \\
\text { Biological control }\end{array}$ & $\begin{array}{c}\text { Ochrona } \\
\text { chemiczna } \\
\text { Chemical control }\end{array}$ & $\begin{array}{c}\text { Kontrola } \\
\text { Control }\end{array}$ & $\begin{array}{l}\text { Razem } \\
\text { Total }\end{array}$ \\
\hline Alternaria alternata (Fr.) Keissler & 6 & 12 & 26 & 44 \\
\hline $\begin{array}{l}\text { Cladosporium cladosporioides } \\
\text { (Fres) de Vries }\end{array}$ & 8 & 4 & 4 & 16 \\
\hline Cylindrocarpon decumbens Corda & 4 & 8 & 24 & 36 \\
\hline $\begin{array}{l}\text { Cylindrocarpon destructans } \\
\text { (Zins.) Scholten }\end{array}$ & 2 & 6 & 16 & 24 \\
\hline $\begin{array}{l}\text { Epicoccum purpurascens } \\
\text { Ehr. ex. Schl. }\end{array}$ & 4 & 2 & - & 6 \\
\hline $\begin{array}{l}\text { Fusarium culmorum } \\
\text { (W. G. Sm.) Sacc. }\end{array}$ & 4 & 6 & 18 & 28 \\
\hline Fusarium oxysporum Schl. & 12 & 8 & 24 & 44 \\
\hline $\begin{array}{l}\text { Penicillium nigricans } \\
\text { (Bain.) Thom }\end{array}$ & 8 & 4 & 10 & 22 \\
\hline $\begin{array}{l}\text { Penicillium purpurescens } \\
\text { (Scopp.) Raper et Thom }\end{array}$ & - & 6 & 4 & 10 \\
\hline Pythium irregulare Buisman & 4 & 10 & 30 & 44 \\
\hline Rhizoctonia solani Kühn & 2 & - & 14 & 16 \\
\hline Rhizopus nigricans Ehrenberg & - & 6 & 2 & 8 \\
\hline Trichoderma harzianum Rifai & 8 & 2 & 2 & 12 \\
\hline Trichoderma koningii Oud. & 10 & 4 & - & 14 \\
\hline $\begin{array}{l}\text { Trichoderma polysporum } \\
\text { (Link ex. Pers.)Rifai }\end{array}$ & 6 & 2 & 4 & 12 \\
\hline Razem Total & 78 & 80 & 178 & 336 \\
\hline
\end{tabular}

Przeprowadzona analiza mikrobiologiczna poszczególnych prób gleby wykazała, że w $1 \mathrm{~g}$ suchej masy gleby występowało od 7,66 x $10^{6}$ do $1,7 \times 10^{6}$ kolonii bakterii (tab. 2). Najmniejszą średnią ogólną liczbą bakterii charakteryzowała się gleba pobrana z kombinacji kontrolnej. 
W przypadku bakterii rodzaju Bacillus liczba kolonii w $1 \mathrm{~g} \mathrm{~s}$. m. gleby była największa w kombinacji po zastosowaniu Polyversum i wynosiła ona średnio 3,08 x $10^{6}$ kolonii. Najmniej zaś kolonii (średnio $0,78 \times 10^{6}$ ) tego rodzaju bakterii było w glebie kontrolnej (tab. 2). Populacja bakterii rodzaju Pseudomonas najliczniej (średnio 0,45 x $10^{6}$ kolonii) reprezentowana była w glebie, na której uprawiano żeń-szeń po zastosowaniu Polyversum, a najmniej (średnio $0,027 \times 10^{6}$ kolonii) bakterii z tego rodzaju uzyskano z gleby kontrolnej. Poszczególne próby gleby różniły się również liczebnością kolonii grzybów (tab. 2). Najwięcej kolonii grzybów było w $1 \mathrm{~g}$ s. m. gleby pochodzącej z kontroli (tab. 2).

Tabela 2

Liczebność bakterii i grzybów wyizolowanych z gleby spod uprawy żeń-szenia (2003-2004)

Table 2

The number of bacteria and fungi isolated from the soil in ginseng cultivation (2003-2004)

\begin{tabular}{|c|c|c|c|c|}
\hline $\begin{array}{c}\text { Kombinacja } \\
\text { doświadczenia } \\
\text { Experimental } \\
\text { combination }\end{array}$ & $\begin{array}{l}\text { Ogólna liczba bakterii } \\
\left.\text { ( } \mathrm{mln} \times \mathrm{g}^{-1} \mathrm{~s} . \mathrm{m} . \mathrm{g}\right) \\
\text { Total number } \\
\text { of bacteria } \\
\left(\mathrm{mln} \cdot \mathrm{g}^{-1} \text { d.w. of soil) }\right.\end{array}$ & $\begin{array}{c}\text { Liczba bakterii } \\
\text { z rodzaju Bacillus } \\
\left(\mathrm{mln} \mathrm{x} \mathrm{g}^{-1} \mathrm{~s} . \mathrm{m} . \mathrm{g}\right) \\
\begin{array}{l}\text { Number of Bacillus } \\
\left(\mathrm{mln} \cdot \mathrm{g}^{-1} \mathrm{~d} . \mathrm{w} \text { of soil) }\right.\end{array}\end{array}$ & $\begin{array}{c}\text { Liczba bakterii } \\
\text { z rodzaju Pseudomonas } \\
\left.\text { (mln } \mathrm{x} \mathrm{g}^{-1} \mathrm{~s} . \mathrm{m} . \mathrm{g}\right) \\
\text { Number } \\
\text { of Pseudomonas } \\
\text { (mln } \cdot \mathrm{g}^{-1} \text { d.w. of soil) }\end{array}$ & $\begin{array}{l}\text { Ogólna liczba grzybów } \\
\text { (tys. x } \mathrm{g}^{-1} \mathrm{~s} . \mathrm{m} . \mathrm{g} \text { ) } \\
\text { Total number } \\
\text { of fungi } \\
\text { (thous. } \mathrm{g}^{-1} \text { d.w. of soil) }\end{array}$ \\
\hline $\begin{array}{c}\text { Ochrona } \\
\text { biologiczna } \\
\text { Biological } \\
\text { control }\end{array}$ & $7,66^{* \mathrm{c}}$ & $3,08^{c}$ & $0,45^{\mathrm{b}}$ & $14,54^{\mathrm{a}}$ \\
\hline $\begin{array}{l}\text { Ochrona } \\
\text { chemiczna } \\
\text { Chemical } \\
\text { control }\end{array}$ & $3,53^{b}$ & $2,27^{\mathrm{b}}$ & $0,08^{\mathrm{a}}$ & $22,21^{b}$ \\
\hline $\begin{array}{c}\text { Kontrola } \\
\text { Control }\end{array}$ & $1,7^{\mathrm{a}}$ & $0,78^{\mathrm{a}}$ & $0,027^{\mathrm{a}}$ & $41,85^{\mathrm{c}}$ \\
\hline
\end{tabular}

* średnie wartości w kolumnach oznaczone tą samą literą nie różnią się istotnie przy P $\leq 0.05$ mean in columns fellowed by the same letter do not differ significantly at $\mathrm{P} \leq 0.05$

Skład gatunkowy grzybów w poszczególnych próbach gleby był zbliżony, jednak różnił się liczebnością kolonii (tab. 3). Najwięcej izolatów grzybów uzyskano z gleby kontrolnej. Gleba z poletek, gdzie stosowano zarówno preparaty chemiczne jak i biopreparat charakteryzowała się podobną liczebnością kolonii grzybów (tab. 3).

$\mathrm{Z}$ badanych prób gleby spośród grzybów patogenicznych najliczniej wyosabniano Pythium irregulare, którego izolaty stanowiły 5,9\% wszystkich wyosobnień. Grzyb ten najczęściej izolowano z gleby pobranej z kombinacji kontrolnej (tab. 3). Ponadto we wszystkich próbach gleby występowały grzyby rodzaju Fusarium reprezentowane przez F. oxysporum i F. solani oraz Alternaria alternata. Natomiast Rhizoctonia solani 
nie był izolowany z prób gleby po zastosowaniu preparatów chemicznych. Z gleby pochodzącej z kombinacji kontrolnej i z kombinacji z zastosowaniem ochrony chemicznej izolowano Cylindrocarpon destructans.

Spośród grzybów saprotroficznych uzyskanych z gleby wszystkich kombinacji doświadczenia najliczniej wyosabniano grzyby rodzaju Penicillium. Znacznie rzadziej uzyskiwano grzyby rodzaju Trichoderma reprezentowane przez T. harzianum, T. polysporum, T. viride (tab. 3). Grzyby tego rodzaju najczęściej uzyskiwano z gleby na której uprawiano żeń-szeń po zastosowaniu Polyversum, a najmniej z kombinacji kontrolnej.

Ponadto grzyby saprotroficzne reprezentowane były przez Epicoccum purpurascens, Mucor hiemalis oraz Rhizopus nigricans (tab. 3).

Tabela 3

Grzyby często izolowane z gleby spod uprawy żeń-szenia (2003-2004)

Table 3

Fungi often isolated in the soil from ginseng cultivation (2003-2004)

\begin{tabular}{|c|c|c|c|c|}
\hline \multirow{2}{*}{$\begin{array}{l}\text { Gatunek grzyba } \\
\text { Fungus species }\end{array}$} & \multicolumn{4}{|c|}{$\begin{array}{l}\text { Liczba izolatów / Kombinacja doświadczenia } \\
\text { Number of isolates / Experimental combination }\end{array}$} \\
\hline & $\begin{array}{l}\text { Ochrona biologiczna } \\
\text { Biological control }\end{array}$ & $\begin{array}{l}\text { Ochrona chemiczna } \\
\text { Chemical control }\end{array}$ & $\begin{array}{c}\text { Kontrola } \\
\text { Control }\end{array}$ & $\begin{array}{l}\text { Razem } \\
\text { Total }(\%)\end{array}$ \\
\hline Alternaria alternata (Fr.) Keissler & 6 & 10 & 7 & $23(3,5 \%)$ \\
\hline $\begin{array}{l}\text { Cylindrocarpon destructans } \\
\text { (Zins.) Scholten }\end{array}$ & - & 2 & 8 & $10(1,5 \%)$ \\
\hline $\begin{array}{l}\text { Epicoccum purpurascens } \\
\text { Ehr. ex. Schl. }\end{array}$ & 10 & 12 & 5 & $27(4,0 \%)$ \\
\hline Fusarium oxysporum Schl. & 12 & 8 & 15 & $35(5,3 \%)$ \\
\hline Fusarium solani (Mart.) Sacc. & 4 & 7 & 12 & $23(3,5 \%)$ \\
\hline Mucor hiemalis Wehmer & - & 8 & 15 & $23(3,5 \%)$ \\
\hline $\begin{array}{l}\text { Penicillium verrucosum Dierckx } \\
\text { var. cyclopium (West.) Samson, } \\
\text { Stolk et Hadlok }\end{array}$ & 50 & 48 & 153 & $251(37,8 \%)$ \\
\hline $\begin{array}{l}\text { Penicillium verrucosum Dierckx } \\
\text { var. verrucosum Samson, } \\
\text { Stolk et Hadlok }\end{array}$ & 20 & 25 & 121 & $\begin{array}{c}166 \\
(25 \%)\end{array}$ \\
\hline Pythium irregulare Buisman & - & 8 & 31 & $39(5,9 \%)$ \\
\hline Rhizoctonia solani Kühn & 3 & - & 9 & $12(1,8 \%)$ \\
\hline Rhizopus nigricans Ehrenberg & 3 & 7 & 4 & $14(2,1 \%)$ \\
\hline Trichoderma harzianum Rifai & 14 & 1 & - & $15(2,3 \%)$ \\
\hline $\begin{array}{l}\text { Trichoderma polysporum } \\
\text { (Link ex. Pers.) Rifai }\end{array}$ & 6 & 7 & 2 & $15(2,3 \%)$ \\
\hline $\begin{array}{l}\text { Trichoderma viride } \\
\text { (Link ex Pers.) Rifai }\end{array}$ & 9 & 1 & - & $10(1,5 \%)$ \\
\hline Razem Total & 137 & 144 & 382 & $\mathbf{6 6 3}(100 \%)$ \\
\hline
\end{tabular}


Spośród Bacillus spp., Pseudomonas spp. i Trichoderma spp. testowanych względem fitopatogenów najwięcej izolatów o antagonistycznym oddziaływaniu było w glebie spod uprawy żeń-szenia chronionego Polyversum. Najmniej zaś takich mikroorganizmów było w glebie kontrolnej (tab. 4). Niewiele więcej w porównaniu do kontroli, występowało antagonistów w glebie po zastosowaniu chemicznej ochrony roślin.

Tabela 4

Antagonistyczne bakterie i grzyby wyizolowane z gleby spod uprawy żeń-szenia (2003-2004)

Table 4

Antagonistic bacteria and fungi isolated from the soil in ginseng cultivation (2003-2004)

\begin{tabular}{|c|c|c|c|}
\hline \multirow{2}{*}{$\begin{array}{c}\text { Bakterie i grzyby } \\
\text { Bacterial and fungus }\end{array}$} & \multicolumn{3}{|c|}{$\begin{array}{c}\text { Liczba izolatów / Kombinacja doświadczenia } \\
\text { Number of isolates / Experimental combination }\end{array}$} \\
\cline { 2 - 4 } & $\begin{array}{c}\text { Ochrona biologiczna } \\
\text { Biological control }\end{array}$ & $\begin{array}{c}\text { Ochrona chemiczna } \\
\text { Chemical control }\end{array}$ & $\begin{array}{c}\text { Kontrola } \\
\text { Control }\end{array}$ \\
\hline Bacillus spp. & 25 & 4 & 2 \\
\hline Pseudomonas spp. & 127 & 42 & 8 \\
\hline Razem Total & $\mathbf{1 5 2}$ & $\mathbf{4 6}$ & $\mathbf{1 0}$ \\
\hline Trichoderma harzianum & 14 & 1 & - \\
\hline Trichoderma polysporum & 6 & 7 & - \\
\hline Trichoderma viride & 9 & 1 & $\mathbf{2}$ \\
\hline Razem Total & $\mathbf{2 9}$ & $\mathbf{9}$ & \\
\hline
\end{tabular}

\section{DYSKUSJA}

Przeprowadzone badania wykazały, że korzenie żeń-szenia porażane były przez takie grzyby patogeniczne jak Alternaria alternata, Pythium irregulare, Rhizoctonia solani oraz grzyby z rodzaju Cylindrocarpon i Fusarium powodujące objawy chorobowe w postaci zgnilizny korzeni czy też rdzawej nekrozy korzeni ustalone wcześniej przez Piętę i B erbecia (1997). Udział grzybów patogenicznych w porażaniu korzeni był różny w poszczególnych kombinacjach doświadczenia. Bezwzględnie najwięcej izolatów grzybów chorobotwórczych było w obrębie kolonii wyosobnionych z korzeni żeń-szenia pobranych z kombinacji kontrolnej tj. bez żadnej ochrony.

W przypadku stosowania Polyversum niektóre fitopatogeny jak Alternaria alternata, Fusarium culmorum i Pythium irregulare oraz Cylindrocarpon spp. miały mniejszy udział w porażaniu żeń-szenia, aniżeli po zastosowaniu ochrony chemicznej. Natomiast preparaty chemiczne zastosowane zarówno do zaprawiania nasion, podlania gleby oraz opryskiwania roślin znacznie ograniczyły porażenie korzeni przez $F$. oxysporum i $R$. solani. Działanie biopreparatu Polyversum zawierającego oospory antagonistycznego grzyba Pythium oligandrum oparte jest na długotrwałym oddziaływaniu 
na patogeny poprzez antybiozę, konkurencję i nadpasożytnictwo (L e v is i in., 1989; $\mathrm{B}$ e $\mathrm{n}$ h a $\mathrm{m}$ o u $\mathrm{i}$ in., 1999). Liczne informacje $\mathrm{z}$ literatury wskazują na skuteczne działanie Polyversum w ograniczaniu chorób roślin (P i c ar d i in., 2000; O r l i k o w s k i , 2001; S a ni ewska, 2001; Orlikowski i in., 2002).

Analizowana gleba pod względem składu mikrobiologicznego różniła się ogólną liczbą bakterii, Bacillus spp, Pseudomonas spp., oraz ogólną liczbą grzybów w poszczególnych kombinacjach doświadczenia. W glebie pochodzącej spod uprawy żeń-szenia po zastosowaniu Polyversum najliczniej izolowano bakterie rodzajów Bacillus i Pseudomonas, a najmniej licznie kolonie grzybów w porównaniu zarówno do kombinacji doświadczenia z chemiczną ochroną, jak i do kontroli.

Gleba pobrana z poletek kombinacji z fungicydami charakteryzowała się małą zawartością mikroorganizmów. Można przypuszczać, że stosowane preparaty chemiczne działały hamująco na ich wzrost i rozwój. Według P i ęt y (1997) preparat Dithane M-45, który uwzględniono w prezentowanych badaniach okazał się silnie ograniczającym fungicydem dla szerokiego spektrum grzybów chorobotwórczych dla żeń-szenia. Należy przypuszczać, że użyte do ochrony żeń-szenia preparaty chemiczne ograniczały także wzrost i rozwój mikroorganizmów antagonistycznych na co wskazuje ich mała liczebność w glebie. W glebie kontrolnej było mało saprotrofów, w tym także antagonistów, bowiem środowisko to zdominowane było przez grzyby chorobotwórcze na co wskazała analiza mikrobiologiczna. Stosowanie preparatów chemicznych jest działaniem szybkim, lecz krótkotrwałym (B o r e c k i 1984). Częste stosowanie fungicydów, co miało miejsce w prowadzonym doświadczeniu, stwarza niebezpieczeństwo powstawania wirulentnych ras fitopatogenów oraz skażenia środowiska i plonu żeń-szenia (B o r e c k i , 1984).

Zastosowanie Polyversum spowodowało również zwiększenie w środowisku glebowym grzybów rodzaju Trichoderma. Należy przypuszczać, że Pythium oligandrum jako silny konkurent bardzo intensywnie się rozwija. Gatunek ten zasiedla coraz to inne nisze ekologiczne w środowisku glebowym wypierając patogeny, na korzyść grzybów saprotroficznych. Ponadto właściwości celulolityczne i chitynolityczne grzybów rodzaju Trichoderma oraz ich zdolności antagonistycznego oddziaływania w stosunku do innych grzybów, zwłaszcza chorobotwórczych mogą istotnie wpływać na zmianę populacji fitopatogenów (P a pavizas, 1985; Ła ci c owa i Pięta, 1989).

\section{LITERATURA}

Attele A., Wu J.A., Yuan C., 1999. Ginseng pharmacology. Multiple consituents and multiple actions. Biochemical Pharm. 58: 1685-1693.

B en ham ou N., Rey P., P ic ard K., Tirilly Y., 1999. Ultrastructural and cytochemical aspect of the interaction between the mycoparasite Pythium oligandrum and soilborne plant pathogens. Phytopathology, 89: 506-517.

B e y fu s s R.L., 1999. American ginseng production in woodlots. Agroforestry Notes, USDA National Agroforestry Center, 14: 1-4. 
B o r e c k i Z., 1984. Fungicydy stosowane w ochronie roślin. PWRiL Warszawa.

F o 11 e t J., 1997. Ginseng production in NZ forests. Experiences from Tikitere. Tree Grower, August,: 19-21.

F unck - J e n s e n D., H o c k e n hull J., 1984. Root exudation, rhizosphere microorganisms and disease control. Växtskyddsnotier, 48: 49-54.

Levis K., Wipps I.M., Cooke R.C., 1989. Mechanisms of biological disease control with special reference to the case study of Pythium oligandrum as an antagonists. Biotechnology of Fungi for Improving Plant Growth I.M. Whipps and R. D. Lumdsen, eds. Cambridge University Press, Cambridge: 191-217.

Li T.S.C., 1995. Asian and American ginseng - a review. Hort. Technology, 5 (1): 27-34.

Łaci cowa B., P i ęt a D., 1989. Szkodliwość grzybów z rodzajów Trichoderma i Gliocladium dla niektórych patogenów fasoli. Zesz. Probl. Post. Nauk Roln., 374: 235-242

M a ń k a K., 1974. Zbiorowiska grzybów jako kryterium oceny wpływu środowiska na choroby roślin. Zesz. Probl. Post. Nauk Roln., 160: 9-23.

M a r t in J.P., 1950. Use of acid, rose bengal an sterptomycin in the method for estimating soil fungi. Soil. Sci., 38: 215-220.

Martyniuk S., Masiak D., Stachyra A., Myśków W., 1991. Populacje drobnoustrojów strefy korzeniowej różnych traw i ich antagonizm w stosunku do Gaemannomyces graminis var. tritici. Pam. Puł. IUNG, 98: 139-144.

Nadeau I., Olivier A., Simard R.R., Coulombe J., Yelle S., 1999. Growing American ginseng in maple forests as an alternative land use system in Quebec, Canada. Agroforestry Systems, 44: 345-353.

Nault A., Gagnon D., White D., Argus G., 1998. Conservation of ginseng in Ontario. Report 1997/1998. Science and Technology - East Science Unit, Ministry of Natural Resources, Toronto, ON: 1-89.

Orlik ow ski L.B., 2001. Biological activity of Pythium oligandrum against Phytophthora species. Proceedings of the $53^{\text {rd }}$ International Symposium on Crop Protection, Gent, Belgium, 8 May. Part I Mededelingen Faculteit-Landbouwkundige-en toegepaste biologische Wetenschappen, Universiteit, Gent, 66, 2a: 161-166.

Orlikowski L.B., Jaworska-Marosz A., Taborsky V. (ed.), Polak J. (ed.), $\mathrm{L}$ e b e d a A. (ed.), K u d e la V., 2002. Influence of Pythium oligandrum on population of Fusarium oxysporum f. sp. dianthi and development of Fusarium wilt of carnation. Disease Resistance in Plant Pathol., Proceedings of the $6^{\text {th }}$ Conference of the European Foundation for Plant Pathol., Prague, Czech Rep. 8-14 September. Plant Protect. Sci. 38, 1: 209-211.

P a pavizas G.C., 1985. Trichoderma i Gliocladium: Biology, ecology and potential for biocontrol. Ann. Rev. Phytopathol., 23: 23-54.

P a rke J.L., S h o tw e 11 K.M., 1989: Disease of cultivated ginseng. Dep. Plant Pathol., University Wisconsin-Madison pp.: 1-16.

Picard K., Ponchet M., Blein J.P., Rey P., Tirlly Y., Benhamou N., 2000. Oligandrin A proteinaceous molecule produced by the mycoparasite Pythium oligandrum induces resistance to Phytophthora parasitica infection in tomato plants. Plant Physiol., 124: 379-395. 
P i ęt a D., 1997. Badania aktywności grzybobójczej fungicydów względem grzybów chorobotwórczych dla żeń-szenia amerykańskiego (Panax quinquefolium L.). Ann. Univ. Marie Curie-Skłodowska, Sect. EEE Hortic.: 211-217.

P i ęt a D., 1999. Initial studies of populations of fungi in the soil under influence of the cultivation of spring wheat and winter wheat in a growth chamber. Acta Agrobot., 52, 1-2: 161-166.

P ięt a D., B e rbeć S., 1995. Grzyby porażające żeń-szeń (Panax quinquefolium L.). Mat. Ogólnopol. Konf. Nauk. „Nauka Praktyce Ogrodniczej”, AR Lublin,: 345-348.

P ięt a D., B e rbeć S., 1997. Choroby żeń-szenia amerykańskiego (Panax quinquefolium L.) powodowane przez grzyby. Ann. Univ. Marie Curie-Sskłodowska, Sect. EEE Hortic.: 219-225.

P unj a Z.K., 1997. Fungal pathogens of American ginseng (Panax quinquefolium) in British Columbia. Can. J. Plant Pathol., 19: 301-306.

S a n i ew ska A., 2001. Utilization of Polyversum bioproduct as a potential protection of Chinese asters against Fusarium oxysporum f. sp. callistephi. Ochr. Rośl. 45: 9-10, 6-7.

\section{Streszczenie}

Badania prowadzono w latach 2003-2004 na plantacji żeń-szenia amerykańskiego (Panax quinquefolium L.) zlokalizowanej w lesie mieszanym w Trzcińcu (woj. lubelskie). Przedmiotem badań była gleba pochodząca spod uprawy żeń-szenia chronionego metodą biologiczną oraz chemiczną. $\mathrm{W}$ doświadczeniu uwzględniono również kombinację kontrolną - bez stosowania zabiegów ochroniarskich. Badaniami objęto także porażone korzenie roślin żeń-szenia. Analiza mikrobiologiczna wykazała, że najmniejszą średnią ogólną liczebnością bakterii charakteryzowała się gleba pobrana z poletek kombinacji kontrolnej. W 1g s. m gleby w kombinacji po zastosowaniu Polyversum stwierdzono najwięcej kolonii bakterii rodzaju Bacillus i Pseudomonas. Najwięcej kolonii grzybów w $1 \mathrm{~g} \mathrm{~s}$. m. gleby uzyskano z kombinacji kontrolnej.

Najwięcej grzybów saprotroficznych w tym o antagonistycznym oddziaływaniu uzyskano z gleby pochodzącej z kombinacji po zastosowaniu biologicznej ochrony roślin.

Rośliny żeń-szenia bez względu na kombinację doświadczenia najczęściej porażane były przez Alternaria alternata, Cylindrocarpon spp., Fusarium spp., Pythium irregulare oraz Rhizoctonia solani. 